\title{
The insecure future of Bulgarian refugial mires: economic progress versus Natura 2000
}

\author{
Michal Hájek, Petra Hájo ová, Iva A pos tolova, Michal Horsák \\ Zuzana Rozbrojová, Desislava Sopothieva and Nikolay Velev
}

\begin{abstract}
Many mires of high conservation value occur in Bulgaria. These mires acted as refugia during the dry phases of ice ages and therefore contain a high number of rare and disjunct species. The mires harbour specific ecotypes and genotypes of plants and animals, and thus provide an opportunity to test biogeographical hypotheses, and they also contain important information about the history of European mires. In this study we ranked all known mire and spring complexes in Bulgaria according to the occurrence of rare and threatened plant and mollusc species. This analysis shows a conspicuous concentration of rare species at several sites, and no correspondence between the importance of individual mires for biodiversity and their legal protection. Of the 10 mire complexes of highest priority only one is effectively protected. The remaining unprotected mires have either been destroyed or are threatened by ongoing development. Having joined the European Union, Bulgaria has built a Natura 2000 network that could provide an opportunity for mire conservation. However, destruction of mire habitats proceeds faster than the approval of Natura 2000 sites. There is thus a possibility that unique Bulgarian mires will be lost before the Natura 2000 system begins to perform its role. Only effective and timely protection of the mire remnants, together with appropriate management, will ensure the future of these unique habitats.
\end{abstract}

Keywords Bulgaria, diversity, mire, Natura 2000, peatland, rare species, refugia, wetland

This paper contains supplementary material that can be found online at http://journals.cambridge.org

\section{Introduction}

$\mathrm{M}$ ires are nutrient-limited, low productivity wetlands accumulating peat or calcareous tufa (Hájek et al.,

Michal Hájek (Corresponding author), Petra Hájková*, Michal Horsák and Zuzana Rozbrojová Department of Botany and Zoology, Faculty of Science, Masaryk University, Kotlářská 2, CZ 61137 Brno, Czech Republic. E-mail hajek@sci.muni.cz

Iva Apostolova, Desislava Sopotlieva and Nikolay Velev Department of Phytocoenology and Ecology, Institute of Botany, Bulgarian Academy of Sciences, Sofia, Bulgaria

*Also at: Department of Ecology, Institute of Botany, Academy of Science of the Czech Republic

Received 10 February 2009. Revision requested 5 May 2009.

Accepted 12 June 2009.
2006) and are amongst the most threatened ecosystems of the European temperate zone (van Diggelen et al., 2006). Mires are important for the study of palaeoecology, hydrology, succession, restoration ecology, population biology, species-environment relationships and the global carbon cycle but such studies are strongly biased towards boreal mires and ombrotrophic bogs (Rydin \& Jeglum, 2006). In contrast to boreal and arctic zones, where mires cover large areas and still widely occur, many mire sites in central and southern Europe have been completely destroyed, drained or modified by human activities. For Bulgaria, Kochev \& Jordanov (1981) estimated the area of all wetlands to be c. 200,000 ha but this has now been reduced to 11,000 ha (Michev, 1995). Starting in the 1920s, and increasing during the 1950s, mires were drained for enlargement of agricultural and urban lands. The construction of reservoirs in basins and valleys rich in mire habitats has been another cause of mire loss in Bulgaria.

Most of the mire remnants in central and western Europe are legally protected, either in national systems of protected areas or in the pan-European system Natura 2000. However, mires in south-east Europe are rarely protected because statutory nature conservation is focused on habitats such as alpine habitats, forests, dry karstic grasslands, reed beds and sea shores, and because there is generally poor awareness of the importance of mires. In addition, there is no tradition of creating small nature reserves in south-east Europe, and many mires are small in area and scattered within the agricultural landscape. In southern Europe Bulgaria is unique because of the occurrence of regions suitable for peat formation such as intermountain basins on impermeable crystalline bedrock and also because both acidic and alkaline wetlands occur (Hájek et al., 2006, 2008; Michev \& Stoyneva, 2007). Therefore, several mire species that are extremely rare or extinct in the other southern European countries (Topić \& Stančić, 2006) are still widespread in Bulgaria (Hájková \& Hájek, 2007; Hájková et al., 2008; Štechová et al., 2008). Because the majority of the Balkan Peninsula is not suitable for the occurrence of mires (Papazisimou et al., 2002; Topić \& Stančić, 2006), many mire species have disjunct distributions in Bulgaria (Hájek et al., 2009; Appendix).

Globally, the uniqueness of Bulgarian mires for biodiversity conservation lies in the high representation of species endemic to these habitats (Hájková et al., 2006) and the disjunct occurrences of many species with boreal and 
arctic distributions, resulting in genetic diversification (Natcheva \& Cronberg, 2003) and local ecotypes (Hájková et al., 2008). From the scientific perspective Bulgarian mires provide opportunities to test biogeographical and ecological hypotheses. The uniqueness of these mires lies in the occurrence of all mire types along the entire $\mathrm{pH} /$ calcium gradient (Hájek et al., 2006, 2008) and the existence of ancient and more recently formed mires (Hájek et al., 2007). The ancient locations act also as natural archives of changes in mire diversity during the Holocene. Dry climatic conditions in the Balkan Peninsula during the last glacial maximum, the late Glacial, and the early Holocene (Wright et al., 2003; Hughes et al., 2006) reduced areas available for survival of mire species in southern Europe.

Effective protection of mire remnants in Bulgaria is important both for biodiversity conservation and because of their irreplaceable scientific importance. Here we rank all known mires in Bulgaria using the occurrence of rare, disjunct species to identify mire complexes that are of high priority for biodiversity conservation. We also compare the list of highpriority sites with the existing network of protected areas and human activities at these sites. We concentrate on plant and mollusc communities, i.e. groups with similar factors controlling their occurrence, although they are not necessarily trophically connected (Horsák et al., 2007).

\section{Methods}

Recent data on species occurrences were taken mostly from vegetation plots (usually of $16 \mathrm{~m}^{2}$; for details see Hájková et al., 2006, 2008; Hájek et al., 2007, 2008) and from checklists of plants and molluscs collected in all types of inland mires, including wetland vegetation around springs and in managed wet grasslands, which may also harbour mire species. We investigated all 240 localities known to contain mire plant species. Molluscs were investigated only at 40 of these localities. Some of the 240 localities are well known whereas we discovered others with the help of old floristic data or during our travels throughout the country. Species found recently by other authors were obtained from the literature (Hájek et al., 2009). The field research was conducted during 2001-2007. For the list of rare species see the Appendix. Our analysis amalgamates some smaller mire sites occurring close together (at scales of hundreds of metres) to the level of mire complexes because they form natural complexes with a presumed metapopulation structure of mire species.

Species predominantly or exclusively inhabiting mire habitats (mire specialists) and that have recently been found only at $\leq 3$ sites were categorized as extremely rare species (Appendix; data from Hájek et al., 2009). Mire specialists that have been found at 4-9 localities were categorized as other rare species (the threshold for molluscs was five occurrences because they were not investigated in all sites). Species found at $>9$ sites but included in national Red Lists (Petrova \& Vladimirov, 2009) or the European Union Habitats Directive (Directive 92/43/EEC) were classified as other red-listed and Habitats Directive species. Ecologically and morphologically unique mire populations of the snail Bulgarica fritilaria were also considered, because they represent the first known treeless fen populations of any door-snail (family Clausiliidae).

To identify the sites most valuable for conservation we applied a simple scoring system: extremely rare species were given scores of 2 , other rare species a score of 1 . As molluscs are under-represented in the species list because of the low number of localities investigated and the smaller species pool and because a high density of mollusc species indicates high habitat quality, especially in fens (Horsák \& Cernohorsky, 2008), an additional score of 1 was assigned to the three sites richest in mollusc species. Mire complexes were then ranked according to the sum of these scores. Thus the 44 mires that had resulting scores of at least 3 are included in Table 1 , in which they are compared with the existing network of protected areas and human activities. Nomenclature follows Andreev et al. (1992), Ganeva \& Natcheva (2003), Natcheva \& Ganeva (2005), Juřičková et al. (2007) and Dedov (1998).

\section{Results}

Of the total of 189 mire plant species that have been recently found in Bulgarian mires, 53 are extremely rare (occurring in 1-3 localities), 25 are rare (4-10 localities) and five are more common ( $>10$ localities) but are red-listed or on the European Union Habitats Directive (Appendix). Thus, 43\% of the mire flora in Bulgaria is threatened in some way. Six mollusc species are important for biodiversity conservation (Appendix). The extremely rare species are concentrated at only a few sites. Eight sites that contain $61 \%$ of all extremely rare species are clearly distinguished by the scoring approach. The final ranking of these eight sites remained the same even when an alternative scoring system for extremely rare species and a different threshold for the designation of species as extremely rare were applied. The highest-ranked sites represent various mire types such as calcareous fens, mineral-rich fens, mineral-poor fens and subalpine mires (for definitions of these terms see Hájek et al., 2006), contain various phytogeographical elements in the group of rare species (Appendix) and occur across the whole geographical range of mire habitats in Bulgaria. Three of the top ranked mire complexes occur in the vicinity of large water reservoirs, which have flooded and destroyed most of their extent (Fig. 1, Table 1; Sites 1, 5 and 7).

There is an apparent lack of correspondence between the scientific and conservation value of the mires and their effective protection in Bulgaria. Of the 10 highest-priority mire complexes only one is effectively protected. Amongst 
TABLE 1 Mires (for locations, see rank numbers in Fig. 1) scoring $\geq 3$ on our scoring system (see text for details), ordered by their scores, with mire type (Hájek et al., 2006)., number of rare species, management type of the mire, threat level, site protection level, whether included in a proposed Natura 2000 site (proposed Sites of Community Importance), occurrence of extremely rare and other rare species (see text for details and Appendix for species' names), and any relevant notes.

\begin{tabular}{|c|c|c|c|c|c|c|c|c|c|c|c|c|}
\hline Rank & Name & Region & $\begin{array}{l}\text { Total } \\
\text { score }\end{array}$ & $\begin{array}{l}\text { Mire } \\
\text { type }^{1}\end{array}$ & $\begin{array}{l}\text { No. of } \\
\text { rare species }\end{array}$ & $\begin{array}{l}\text { Manage- } \\
\text { ment }^{2}\end{array}$ & $\begin{array}{l}\text { Threat } \\
\text { level }^{3}\end{array}$ & $\begin{array}{l}\text { Site protection } \\
\text { level }^{4}\end{array}$ & $\begin{array}{l}\text { Proposed Natura } \\
2000 \text { site }\end{array}$ & $\begin{array}{l}\text { Extremely } \\
\text { rare species }\end{array}$ & Other rare species & Notes $^{5}$ \\
\hline 2 & Krushe & Pirin & 20 & $\mathrm{CF}$ & 13 & Graz & $! ! ! 6^{6}$ & & Yes & $23,31,33,42,45,53$ & $58,64,78,81,83,85,87$ & 1 \\
\hline 3 & Tsraklevtsi & Znepole & 17 & $\mathrm{CF}$ & 10 & Mow & $! ! !$ & & Yes & $4,5,32,38,41,44,51$ & $60,62,78$ & 4 \\
\hline 5 & Belmeken & Rila & 16 & $\mathrm{SaF}$ & 12 & Tram & $! ! ?^{7}$ & NP & Yes & $30,35,36,46$ & $55,56,62,66,78,84,85,86$ & 3 \\
\hline 6 & Dunavtsi & Tundzha region & 15 & $\mathrm{CF}$ & 9 & Mow & $! ! ! ?^{7}$ & & Yes & $3,7,14,48,49$ & $64,78,87,89$ & 1,2 \\
\hline 7 & Shiroka Polyana & Rhodopes & 14 & $\mathrm{PF}$ & 11 & Tram & $\dddot{! ! !}$ & & Yes & $24,50,54$ & $67,68,72,73,74,75,79,84$ & \\
\hline 8 & Smolyan lakes & Rhodopes & 13 & $\mathrm{PF}$ & 11 & Tram & $! ! !^{6}$ & NM & Yes & 10,34 & $57,59,62,63,64,73,82,83,88$ & 2,5 \\
\hline 11 & Chairi lakes & Rhodopes & 9 & $\mathrm{PF}$ & 7 & None & !!! & PA & Yes & 10,27 & $63,67,68,75,82$ & \\
\hline 12 & Topilata-Varla & Rila & 9 & $\mathrm{SaF}$ & 7 & Tram & & NP & Yes & 22,17 & $55,56,57,85,86$ & \\
\hline 13 & Bolovan & Stara Planina & 9 & $\mathrm{SaF}$ & 7 & Graz & $! !$ & NP & Yes & 23,37 & $66,67,74,75,88$ & \\
\hline 14 & Popovi livadi & Pirin & 9 & $\mathrm{CF}$ & 7 & Graz & !!! & & Yes & 45 & $61,62,63,86,87,88$ & 1 \\
\hline 15 & Lozen springs & Sredna Gora & 9 & CF,ERF & 5 & Graz & $! !$ & & No & 16,20 & $58,78,87$ & \\
\hline 16 & Bogdan region & Sredna Gora & 8 & MRF & 7 & Graz & $! !$ & & Yes & 29 & $58,61,77,82,83,84$ & \\
\hline 17 & Torfen Rezervat & Vitosha & 7 & $\mathrm{SaF}$ & 7 & None & !!! & $\mathrm{NR}, \mathrm{NPa}$ & Yes & & $62,67,69,70,74,75,82$ & 3,4 \\
\hline 23 & Drushlyavica & Rila & 5 & $\mathrm{SaF}$ & 4 & None & & NP & Yes & 52 & $55,56,70$ & \\
\hline 24 & Kupena & Rhodopes & 5 & $\mathrm{PF}$ & 3 & Tram & & NR & Yes & 7,9 & 68 & \\
\hline 25 & Zavrachitsa & Rila & 5 & $\mathrm{SaF}$ & 3 & Tram & & NP & Yes & 15,52 & 85 & \\
\hline 26 & Vezhen region & Stara Planina & 5 & $\mathrm{PF}, \mathrm{SaF}$ & 4 & Graz & $!$ & NP & Yes & 6 & $65,72,82$ & \\
\hline 27 & Yasenovo & Stara Planina & 5 & $\mathrm{CF}$ & 3 & None & & & Yes & 3,12 & 64 & \\
\hline 28 & Kom & Stara Planina & 4 & $\mathrm{SaF}$ & 4 & Tram & $!$ & & Yes & & $56,71,75,82$ & \\
\hline 29 & Kolarovo & Struma Valley & 4 & $\mathrm{CF}$ & 2 & Tram & & PA & Yes & 39 & 59,76 & \\
\hline 30 & Mugla & Rhodopes & 3 & CF,ERF & 3 & Graz & $!$ & & Yes & 25 & 88 & \\
\hline 31 & Angelov vrah & Rila & 4 & $\mathrm{SaF}$ & 3 & None & & NP & Yes & 11 & 55,85 & \\
\hline 32 & Osogovo Mt & W Frontier Mts & 4 & MRF & 3 & Graz & $!$ & & Yes & 47 & 70,71 & \\
\hline 33 & Vihren & Pirin & 4 & $\mathrm{CF}$ & 2 & None & !!! & NP & Yes & 1,8 & & \\
\hline 34 & Vitosha-NW part & Vitosha & 4 & PF,MRF & 2 & None & !!! & NP & Yes & 28,43 & & \\
\hline 35 & Bukata & Rila & 4 & ERF & 4 & Graz & $!$ & & Yes & & $62,68,78,86$ & \\
\hline 36 & Valyavishki ezera & Pirin & 3 & $\mathrm{SaF}$ & 2 & None & & NP & Yes & 18 & 62 & \\
\hline 37 & Kochmara & Stara Planina & 3 & $\mathrm{SaF}$ & 2 & Graz & !! & NP & Yes & 21 & 73 & \\
\hline
\end{tabular}




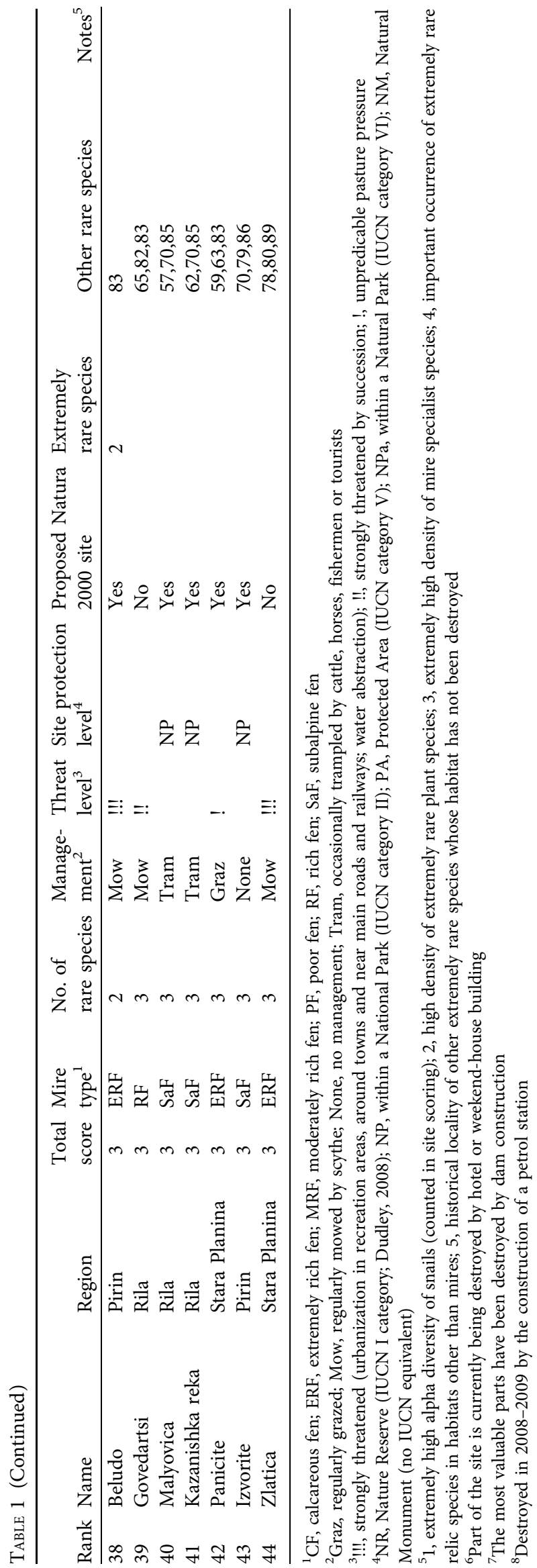

the other top 44 ranked sites (Table 1) 17 are included in National Parks (IUCN category II; Dudley, 2008), mostly in the alpine zone of high mountains. Only two are strict nature reserves (IUCN category I). The others are subject of a lower level of protection, which would not prohibit construction works in the vicinity. The unprotected mires are threatened by a range of human impacts (Table 1 ).

\section{Discussion}

All of the important Bulgarian mire complexes summarized in Table 1 are unique in Europe. The vegetation of Bulgarian mires comprises a unique mixture of widespread mire specialists, Balkan endemics, disjunct arctic-alpine species, and acidophile ecotypes of otherwise calcareous-fen species (Hájková et al., 2006, 2008). While boreal and arctic-alpine species dominate at high altitudes, rare species with a continental distribution prevail at altitudes $<1,000 \mathrm{~m}$.

The Batak mire (Fig. 1; Site 1) represents a remnant of a large mire complex. Its original area of $c .16 \mathrm{~km}^{2}$ consisted of a permanent water basin fluctuating in size surrounded by a complex of fen meadows (Jordanov, 1934). This hydrological setting promoted a high diversity of mire species. The occurrence of the boreal species Carex lasiocarpa, Carex buxbaumii s.s. and Calliergon giganteum suggests an old history, which could be another reason for the high diversity of species in this mire.

The Krushe fen-complex in the Pirin Mountains (Fig. 1; Site 2) harbours 13 rare species of which Ligularia sibirica, Laserpitium archangelica, Valeriana simplicifolia and Polygala amarella are single occurrences and have never been found elsewhere in Bulgaria. However, these species are only sparsely distributed across the Krushe fens. This could be caused by the pioneer character of these spring fens, which probably undergo temporal shifts in their position and thus limit the occurrence of species with low dispersal ability (cf. Wolejko et al., 1994).

Continental species are the most typical in the wetland complex close to the village of Tsraklevtsi (Fig. 1; Site 3), where one of the most hydrologically unique fen complexes occurs. Species-rich continental wet grasslands have been known for a long time at this locality, whereas the uniqueness of the site for conservation has been discovered only recently. Rare fen species are concentrated in several patches at the lowest points: karstic seepages seasonally inundated by groundwater, mostly in spring and in summer after heavy rainfalls. Within the European Union similar habitats are known only in Slovenia and Ireland (Sheehy Skeffington et al., 2006) where they are protected. In the Bulgarian site some regionally rare species (Salix rosmarinifolia, C. buxbaumii s.s., Plantago maxima and Stellaria palustris) occupy two acidic patches, with a $\mathrm{pH}$ of 5.6-5.8, in the calcareous landscape matrix. This patchiness does not correspond to the geological bedrock and can only be 


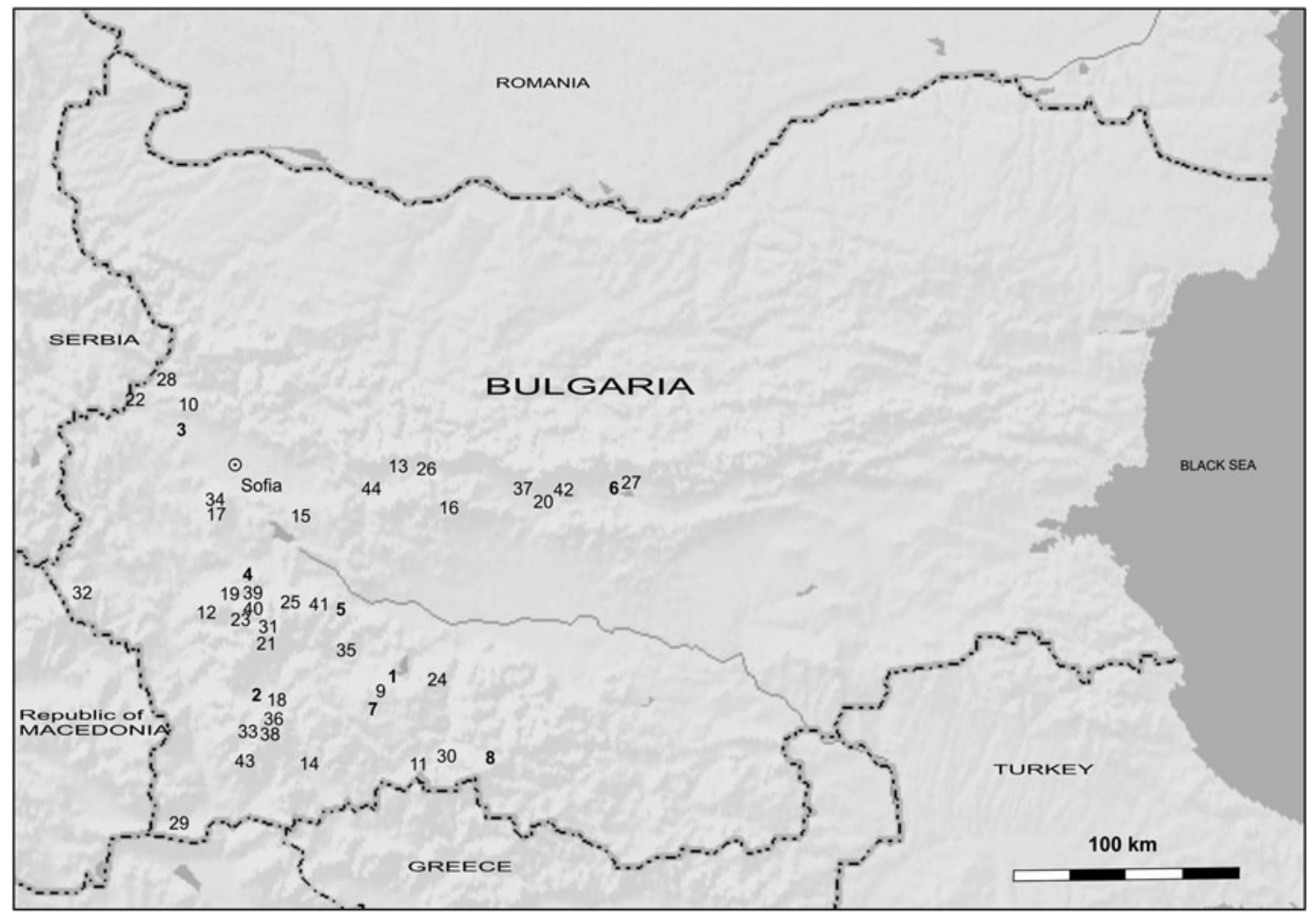

FIG. 1 Location of the 44 mires in Bulgaria considered to be of particular conservation concern (numbers correspond to the ranks in Table 1).

explained by earlier peat deposition, which makes these patches important for future palaeoecological research.

Slightly acidic fens around the town of Samokov (Fig. 1; Site 4) contain both boreal and continental rare species. Boreal and arctic-alpine mire species are typical especially of subalpine and alpine wetlands, represented by fens in the Belmeken region (Fig. 1; Site 5). The presence of the extremely rare species Meesia longiseta, Meesia uliginosa, Scorpidium revolvens s.s. and Juncus triglumis is probably caused by the past existence of large mires situated at the boundary between montane and subalpine vegetation belts, which were lost in the construction of the Belmeken water reservoir.

The most lowland and most mineral-rich fens occur in the basin around the town of Kazanlak (Fig. 1; Site 6, Dunavtsi). The rare species that give this site its high conservation value represent a phytogeographical group that is not found amongst the rare species in other mires. They have a European temperate distribution that mirrors the distribution of lowland calcareous fens on deep sediments from south-west Europe through central European Cretaceous basins to the landscape surrounding the Baltic Sea (e.g. Cladium mariscus, Schoenus nigricans, Sesleria uliginosa and Campyliadelphus elodes). Jordanov et al. (1972), who first described these fens, noted that the calcareous fen species occupying the fens of the Kazanlak basin were widely distributed and often occurred together during the Pleistocene, and that the local climate together with plentiful springs enable a continuous growth of vegetation during winter, contributing to the uniqueness of this mire refugium. The mollusc fauna of the Dunavtsi fens is also unique. The only fen populations of the family Clausiliidae, an ecologically unique form related to the dry-habitat species $B$. fritilaria (M. Horsák, unpubl. data), occur here.

Boreal species are also typical of the poor fens of the conifer forest zone of the Rhodope Mountains. The site Shiroka Polyana (Site 7) comprises many small mires distributed around an artificial water reservoir. Individual mires are evidently the remnants of a formerly large mire. The palynological data show that the origin of the present vegetation of the region could be related to the late Glacial period (Filipovitch \& Lazarova, 2003).

The site Smolyan lakes (Site 8) belongs, together with Chairi lakes (Site 11), to hydrologically unique mires, which are floating poor fens, where fen vegetation occurs as thin vegetation rafts formed by the entangled rhizomes of Menyanthes trifoliata, Carex limosa and Potentilla palustris growing over deep water. Gaps created by fishermen allow the rare, disjunct species Lycopodiella inundata to grow there.

\section{Recent threats}

Human activities over the last few decades have probably damaged or destroyed Bulgarian mires more than the climate changes of the past 20,000 years. It is possible that even during bottlenecks caused by dry phases in the Pleistocene the extent of mire habitats was higher than at present. 
The main period of mire deterioration was that of large water reservoir construction and drainage of wetlands in the 1950s, which dramatically restricted the total extent of mires. The loss of six disjunct occurrences of mire plants in the Rhodope Mountains (Calamagrostis canescens, Gladiolus palustris, Pseudocalliergon trifarium, Sagina nodosa, Sphagnum obtusum and Sphagnum riparium; Hájek et al., 2009) is associated with the destruction of mires during construction of water reservoirs. During the second half of the 2oth century several mires that were important refugia were either completely destroyed or damaged by human activities. Complete destruction affected the mostly lowland calcareous fens of Choklyovo (with Peucedanum palustre, S. rosmarinifolia and Pedicularis palustris), Kazichene (P. palustris) and Sadovsko blato (Schoenus ferrugineus; cf. Jordanov, 1934). We could not study these three sites because they had already been completely destroyed. Partial degradation can be seen in mires in the Vitosha region, which would otherwise play a more important role in our site ranking. Several important disjunct species have not been recorded there recently (Carex heleonastes, C. limosa and Eriophorum gracile), probably because of water extraction.

In joining the European Union, Bulgaria was obliged to create a national Natura 2000 network. This network covers nearly all 44 top-ranked sites presented in Table 1 and is a promising legal measure for their preservation. However, the third phase of mire deterioration began just before Bulgaria joined the European Union and during the first years of its membership, and there is thus a lack of effective legal protection for the most important mire complexes. Ongoing development, which is often funded by foreign sources, is causing a loss of mire remnants and is proceeding faster than the approval of Natura 2000 sites. This is of serious concern for the future of these irreplaceable habitats. The most important mires occur in areas being developed for tourism or that are close to main roads. The first, second, fourth and eighth highest-ranked sites are being destroyed by the construction of hotels (Krushe and Smolyan lakes), private weekend houses (Batak) and a petrol station (Samokov). The paradox is that economic progress that began after joining the European Union has caused deterioration of mire habitats: completion of the Natura 2000 system of protected areas is not required for new member countries at the time of their entry into the Union. Unique Bulgarian mires will probably be lost before the Natura 2000 system starts to perform its role.

\section{Considerations for future management}

The restoration prospects for severely degraded mires are generally poor (Grootjans et al., 2006). Building is occurring rapidly at Batak, Krushe, Smolyan and Samokov and every year new buildings replace a part of the remnant mires. Drainage, infrastructure development and the need for drinking water will continue to cause irreversible hydrological changes. Local interference in the hydrological regime together with the large-scale processes of intensive forest exploitation and climate change will cause a continuous drying up of the remaining mires. Natura 2000 could be the mechanism for the conservation of important mire remnants but urgent action is required. During the initiation of the Natura 2000 network national legislation requires evaluation of the impact of further investments on each Natura 2000 site. This does not, however, stop ongoing building activities.

We recommend that all important mires be legally protected as strict nature reserves, as soon as possible, to prevent further construction activities, drainage and afforestation. Building activities at our eight highest ranked mires need to be halted and an effort made to preserve those mire remnants that have survived (and that are threatened by water pumping, eutrophication, waste deposition and other factors). The sites that are not affected by the current building boom should be regularly mown to prevent successional changes, litter accumulation and the expansion of dominant grasses. Regulation of tourism could help save mire remnants in localities that are widely used for summer camping. Finally, we believe that raising public awareness of the irreplaceable value of mires is the most important way to save the mires of Bulgaria.

\section{Acknowledgements}

We thank the Grant Agency of the Czech Academy of Sciences for supporting research on Bulgarian wetlands during 2003-2005 (project GAAV No. B6163302) and research on plant and snail refugia (No. B601630803). The research and manuscript preparation were also supported by the long-term research plans of Masaryk University (Czech Ministry of Education, MSM 0021622416) and the Institute of Botany, Academy of Sciences (AVZ0Z60050516), a joint research project between the Bulgarian and Czech Academy of Sciences (2005-2007) and by doctoral grant GAČr no. 526/09/H025. We thank John Rodwell, Jon Shaw and anonymous reviewers for valuable comments.

\section{References}

Andreev, N., Anchev, M., Kozhuharov, S., Markova, M., Peev, D. \& Petrova, A. (1992) Field Guide to the Vascular Plants in Bulgaria. Nauka i Izkustvo, Sofia, Bulgaria. [in Bulgarian]

Dedov, I. (1998) Annotated check-list of the Bulgarian terrestrial snails (Mollusca, Gastropoda). Linzer Biologische Beiträge, 30, 745765 .

Directive 92/43/EeC (1992) Council Directive 92/43/EEC of 21 May 1992 on the Conservation of Natural Habitats and of Wild Fauna and 
Flora. OJ L 206, 22.07.1992, pp. 7-50. European Commission, Brussels, Belgium.

Dudley, N. (ed.) (2008) Guidelines for Applying Protected Area Management Categories. IUCN, Gland, Switzerland.

Filipovich, L. \& Lazarova, M. (2003) Palynological research in the Shiroka Polyana locality (Western Rhodopes). Phytologia Balcanica, 9, 265-273.

Ganeva, A. \& NATCHEVA, R. (2003) Checklist of the bryophytes of Bulgaria with data on their distribution. I. Hepaticae and Anthocerotae. Cryptogamie Bryologie, 24, 229-239.

Grootjans, A.P., Adema, E.B., Bleuten, W., Joosten, H., Madaras, M. \& Janáková, M. (2006) Hydrological landscape settings of base-rich fen mires and fen meadows: an overview. Applied Vegetation Science, 9, 175-184.

Hájek, M., HÁjková, P. \& A postolova, I. (2008) New plant associations from Bulgarian mires. Phytologia Balcanica, 14, 377399.

Hájek, M., Hájková, P., Apostolova, I., Horsák, M., Plášek, V., Shaw, B. \& LaZarova, M. (2009) Disjunct occurrences of plant species in the refugial mires of Bulgaria. Folia Geobotanica, $44,365-386$.

Hájek, M., Horsák, M., Hájková, P. \& Dítě, D. (2006) Habitat diversity of central European fens in relation to environmental gradients and an effort to standardize fen terminology in ecological studies. Perspectives in Plant Ecology, Evolution and Systematics, 8, 97-114.

HájeK, M., TíhÝ, L., SChamp, B.S., ZelenÝ, D., Roleček, J., HÁjkové, P. et al. (2007) Testing the Species Pool Hypothesis for mire vegetation: exploring the influence of $\mathrm{pH}$ specialists and habitat history. Oikos, 116, 1311-1322.

HÁjKovÁ, P. \& HÁJEK, M. (2007) Sphagnum distribution patterns along environmental gradients in Bulgaria. Journal of Bryology, 29, $18-26$.

Hájková, P., Hájek, M. \& A postolova, I. (2006) Diversity of wetland vegetation in the Bulgarian high mountains, main gradients and context-dependence of the $\mathrm{pH}$ role. Plant Ecology, $184,111-130$.

Hájková, P., Hájek, M., A postolova, I., Zelený, D. \& Dítě, D. (2008) Shifts in the ecological behaviour of plant species between two distant regions: evidence from the base richness gradient in mires. Journal of Biogeography, 35, 282-294.

Horsák, M. \& Cernohorsky, N. (2008) Mollusc diversity patterns in Central European fens: hotspots and conservation priorities. Journal of Biogeography, 35, 1215-1225.

Horsák, M., HÁjek, M., Dítě, D. \& Tichý, L. (2007) Modern distribution patterns of snails and plants in the Western Carpathian spring fens: is it a result of historical development? Journal of Molluscan Studies, 73, 53-60.

Hughes, P.D., Woodward, J.C. \& Gibbard, P.L. (2006) Late Pleistocene glaciers and climate in the Mediterranean. Global and Planetary Change, 50, 83-98.

Jordanov, D. (1934) Phytogeographical studies of Bulgarian wetlands in relation to their higher plant vegetation. I. Inland wetlands. Annuaire de L'Universite de Sofia, Faculte PhysicoMatematique, 27, 75-156. [in Bulgarian]

Jordanov, D., Ganchev, S., Denchev, S., Meshinev, T. \& Nikolov, N. (1972) Some new data on the spread and ecologicgeographic characteristics of several plants from the western part of the Kazanlak valley. Izvestiya na Botanicheskiya Institut BAN, Sofia, 22, 135-141. [in Bulgarian]

JuŘičKová, L., Horsák, M., Beran, L. \& Dvořák, L. (2007) Checklist of the Molluscs (Mollusca) of the Czech Republic. Http://mollusca.sav.sk/malacology/checklist.htm [accessed 18 June 2007].
Kochev, H. \& Jordanov, D. (1981) Vegetation of Water Basins in Bulgaria. Academic Publishing House, Sofia, Bulgarian. [in Bulgarian]

Michev, T. (ed.) (1995) National Action Plan for the Conservation of the Most Important Wetlands in Bulgaria. Ministry of Environment, Sofia, Bulgaria. [in Bulgarian]

Michev, T.M. \& Stoyneva, M.P. (eds) (2007) Inventory of Bulgarian Wetlands and their Biodiversity. Part 1: Non-lotic Wetlands. Publishing House Elsi-M, Sofia, Bulgaria.

Natcheva, R. \& Cronberg, N. (2003) Genetic diversity in populations of Sphagnum capillifolium from the mountains of Bulgaria, and their possible refugial role. Journal of Bryology, 25, 91-99.

NAtcheVA, R. \& GAneva, A. (2005) Checklist of the bryophytes of Bulgaria with data on their distribution. II. Musci. Cryptogamie Bryologie, 26, 209-232.

Papazisimou, S., Bouzinos, A., Christanis, K., Tzedakis, P.C. \& KalaitZidis, S. (2002) The upland Holocene transitional mires of Elatia forest, northern Greece. Wetlands, 22, 355-365.

Petrova, A. \& Vladimirov, V. (eds) (2009) Red List of Bulgarian vascular plants. Phytologia Balcanica, 15, 63-94.

Rydin, H. \& Jeglum, J. (2006) The Biology of Peatlands. Oxford University Press, Oxford, UK.

Sheehy Skeffington, M., Moran, J., Connor, Á.O., Regan, E., Coxon, C.E., Scott, N.E. \& Gormally, M. (2006) TurloughsIreland's unique wetland habitat. Biological Conservation, 133, 265-290.

Štechová, T., Hájek, M., Hájková, P. \& Navrátilová, J. (2008) Comparison of habitat requirements of the mosses Hamatocaulis vernicosus, Scorpidium cossonii and Warnstorfia exannulata in different parts of temperate Europe. Preslia, 80, $399-410$.

TopiĆ, J. \& STANČić, Z. (2006) Extinction of fen and bog plants and their habitats in Croatia. Biodiversity and Conservation, 15, 33713381.

van Diggelen, R., Middleton, B., Bakker, J., Grootjans, A. \& W ASSEn, M. (2006) Fens and floodplains of the temperate zone: present status, threats, conservation and restoration. Applied Vegetation Science, 9, 157-162.

Wolejko, L., Aggenbach, C., Van Diggelen, R. \& Grootjans, A.P. (1994) Vegetation and hydrology in a spring mire complex in western Pomerania, Poland. Proceedings van de Koninklijke Nederlandse Academie van Wetenschappen, 97, 219-245.

Wright, Jr, H.E., Ammann, B., Stefanova, I., Atanassova, J., Margalitadze, N., Wick, L. \& Blyakharchuk, T. (2003) Late-glacial and early-Holocene dry climates from the Balkan Peninsula to Southern Siberia. In Aspects of Palynology and Palaeoecology (ed. S. Tonkov), pp. 127-136. Pensoft Publishing, Sofia, Bulgaria and Moscow, Russia.

\section{Appendix}

The appendix for this article is available online at http:// journals.cambridge.org

\section{Biographical sketches}

Michal Hájek and Petra Hájková are interested in speciesenvironment relationships in European wetlands, especially in the Carpathian-Balkan region. Although they are predominantly focused on vascular plants and bryophytes, their research interests also include the 
coincidences between different biotic assemblages. Iva A postolova researches the diversity, ecology and conservation of the vegetation of the Balkans, with a special emphasis on grasslands and on habitat diversity with respect to Natura 2000. MiChal Horsák is a malacologist interested in the community ecology of Central European molluscs and Quaternary malacology, with a special interest in the mollusc communities of mires. ZUZANA RozBRoJOVÁ is a plant ecologist working on mire and grassland ecology, including the effects of nutrient availability and large-scale vegetation patterns. Desislava Sopotlieva and Nikolay VELEV are vegetation scientists working on mesic, wet and fen grasslands in the Balkan region. 